on the 'alternative' Tropical Forest Action Plan proposed by the World Rainforest

Movement, in which the straps might be untied. His final sentence is, 'In the end, however, it is pointless to tell the Third World to stand on its own two feet when we in the West continue to stand on its hands.' Tony Whitten.

\section{Painted Wolves: Wild Dogs of the Serengeti-Mara Jonathan Scott Hamish Hamilton, London, 1991, 233 pp., HB £25.00}

It may seem odd, at first, that Jonathan Scott feels the need to Anglicize the Latin Lycaon pictus (Lycaon means wolf; pictus means painted or ornate) and rebaptize the species the 'African painted wolf'. After all, the species is more commonly known as the wild dog, or Cape hunting dog. But the wild dog is neither 'wild' (in either the sense of vicious or feral), nor is it closely related to the dog that sits by the fire. And sadly, Lycaon pictus has not been sighted anywhere near the Cape for decades. African painted wolf, however, does describe the striking colouration and instantly identifies the species as the ecological replacement for the true wolf, Canis lupus, south of the Sahara.

But there is more in a name than its meaning. By emphasizing in his title, and in the common name, the beauty of the species, Scott foreshadows the not-so-hidden agenda of the book: to convince the world that painted wolves, rather than being 'vicious killers', are elegant animals deserving of our attention. Scott fulfils his agenda admirably. This book combines extensive and remarkable photographic illustrations (which won him the
BBC Wildlife Photographer of the Year in 1987) with a wealth of scientific data. Scott writes clearly without diluting information, providing the reader with an accurate and entertaining description of painted-wolf biology in the plains of the Serengeti-Mara. He frequently refers to his collaboration with scientists working in the Serengeti-Mara and it is this collaboration that helps bring the book to life. This is the story of not just a single pack of dogs, but of the biology and future conservation of a species living in one of the world's best studied and most spectacular ecosystems

For decades, African wild dogs have been subject to greater persecution that any other large predator in Africa. This persecution-as Scott demonstrates elegantly with an abundance of historical quotations-results from their method of hunting.

Disembowelling one's prey is both messy and, to human observers, 'cruel'. As a result, this species has been extirpated in 19 of 32 countries in which they were once found (Ginsberg and Macdonald, 1990): they are uncommonly rare in all but a few countries. As there are probably fewer wild dogs in protected areas than black rhinos in Africa (Fanshawe et al., pp. this issue), time is running out for the painted wolf.

Not since van Lawick and van Lawick-Goodall's Innocent Killers (1970) and Hugo van Lawick's Solo (1973) have wild dogs, or painted wolves, had such an eloquent advocate. The Serengeti-Mara is not, perhaps, the last best hope for painted wolves in Africa (larger populations exist in Kruger National Park in South Africa, northeastern Botswana, Hwange National Park in Zimbabwe, and Selous Game Reserve in Tanzania). But Painted Wolves: Wild Dogs of the Serengeti-Mara, in its abundance of detail and visual distinction, will draw attention to the plight of wild dogs across Africa.

\section{References}

Fanshawe, J.H., Frame, L.H. and Ginsberg, J.R. In press. Africa's disappearing carnivore: the wild dog. Oryx in press.

Ginsberg, J.R. and Macdonald, D.W. 1990. Foxes, Wolves, Jackals and Dogs: An Action Plan for the Conservation of Canids. 1991 IUCN, Gland, Switzerland.

van Lawick, H. 1973. Solo.

Collins, London.

van Lawick, $H$. and van

Lawick-Goodall, J. 1970.

Innocent Killers. Collins,

London.

Joshua R. Ginsberg.

\section{The Mountain Gorilla}

Boyd Norton

Swan Hill Press, Airlife

Publishing, Shrewsbury, 1990, 128 pp., HB $£ 16.95$

Books on the mountain gorilla are becoming frequent but this is one of the good ones. The photographs are truly evocative and a real effort has been made to set the historical background of gorilla conservation and to encompass the many and varied issues.

These issues include the ambiguities, particularly regarding tourism. Boyd Norton is evidently protourism (and indeed visits as a tourist himself) but is anxious about the risks involved and particularly that of transferring disease from humans to gorillas. I am glad he highlights this problem because it is one that all people coming into contact with the gorillas must be aware of. It must be said, however, 